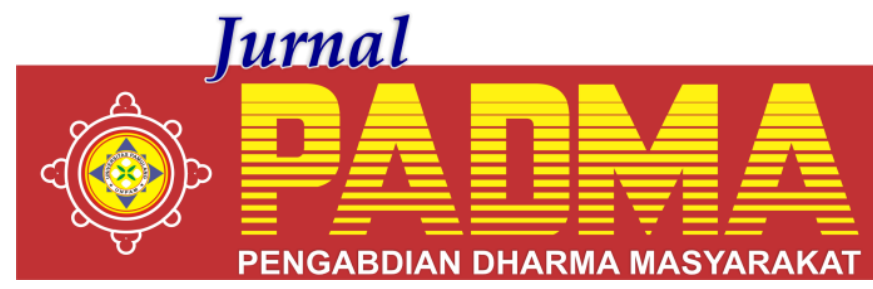

VOLUME 1, NOMOR 2, APRIL 2021

\title{
STRATEGI PEMBERDAYAAN DALAM MENGOPTIMALKAN POTENSI AGRIBISNIS DI PEDESAAN
}

(Kasus : Kec. Cilengkrang, Kelurahan Ciporeal, Desa Cipatat Jawa Barat)

\begin{abstract}
${ }^{1 *}$ Mariana Rachmawati, ${ }^{2}$ Annisa Lisdayanti, ${ }^{3}$ Ni Putu Nurwita Pratami Wijaya, ${ }^{4}$ Gallang Perdana Dalimunthe, 5 Dinda Kayani Putri Bestari, 6 Fansuri Munawar, 7 Uce Karna Suganda
\end{abstract}

Universitas Widyatama , Bandung, Jawa Barat, Indonesia *mariana.rachmawati@widyatama.ac.id

\begin{abstract}
Abstrak
Bila suatu daerah mempunyai potensi bercocok tanam, agribisnis adalah salah satu bidang usaha yang menguntungkan. Namun, dalam pengembangannya dibutuhkan ilmu yang mumpuni agar bisa menghasilkan uang. Karena Dalam kehidupan sehari-hari, sayur , buah dan sus pasti ada di meja makan untuk konsumsi masyarakat. Kebutuhan sayur, buah dan susu ini termasuk kebutuhan pokok karena termasuk makanan yang wajib ada, demi menjaga kesehatan. Sayur-mayur dan buah-buahan dan susu ini termasuk dalam salah satu jenis bisnis agribisnis. Agribisnis adalah potensi yang luar biasa karena sifatnya yang merupakan kebutuhan pokok. Ada berbagai sektor agribisnis yang bisa dikembangkan seperti tanaman obat, sayuran konsumsi, susu, peternakan, dan masih banyak lagi yang lainnya.Namun, saat ini permintaan tak sebanding dengan jumlah produksinya, sehingga beberapa kebutuhan masih harus mengimpor. Hal ini dikarenakan sebagian besar agribisnis dianggap bisnis yang menghasilkan keuntungan sedikit dan melelahkan. Padahal agribisnis adalah peluang bagi Petani dan peternak untuk mengambil kesempatan agar menghasilkan keuntungan yang berlimpah. Kebutuhan akan pangan sangatlah tidak terbatas, sehingga agribisnis adalah bisnis yang punya peluang cukup besar di masa kini maupun di masa yang akan datang.Dan bila kualitias produk Agribisnis ini memiliki karakteristik produk yang sesuai dengan keinginan konsumen, Petani dan peternak bisa memiliki daya saing yang tinggi di pasar domestik dan juga mancanegara.Hal ini yang menjadi tujuan kegiatan PKM Universitas Widyatama di Desa Cipatat Kec. Cilengkrang, Kelurahan Ciporeal, Jawa Barat dalam Strategi Pemberdayaan Agribisnis, Strategi Pemasaran mengembangan dan Mengoptimalkan Potensi Agribisnisnya.
\end{abstract}

Kata Kunci : Agribisnis, Strategi Pemasaran

\begin{abstract}
If an area has the potential for farming, agribusiness is one of the profitable business fields. However, in its development, qualified knowledge is needed in order to make money. Because in everyday life, vegetables, fruit and milk must be on the dining table for public consumption. The needs for vegetables, fruit and milk are included as basic needs because they include food that must be available, in order to maintain health. These vegetables and fruits and milk are included in one type of agribusiness business. Agribusiness is a tremendous potential because it is a basic necessity. There are various agribusiness sectors that can be developed, such as medicinal plants, consumption vegetables, milk, livestock, and many others. However, currently demand is not proportional to the amount of production, so some needs still have to be imported. This is because most of the agribusiness is considered a business that generates little profit and is tiring. Whereas agribusiness is an opportunity for farmers and breeders to take the opportunity to generate abundant profits. The need for food is very unlimited, so that agribusiness is a business that has considerable opportunities today and in the future. And if the quality of this Agribusiness product has product characteristics that are in accordance with consumer desires, farmers and breeders can have high competitiveness. in the domestic and foreign markets. This is the goal of PKM activities at Widyatama University in Cipatat Village, Kec. Cilengkrang, Ciporeal Village, West Java in the Agribusiness Empowerment Strategy, Marketing Strategy to develop and Optimize its Agribusiness Potential.
\end{abstract}

Keywords: Agribusiness, Marketing Strategy 


\section{PENDAHULUAN}

Bila suatu daerah mempunyai potensi bercocok tanam, agribisnis adalah salah satu bidang usaha yang menguntungkan. Namun, dalam pengembangannya dibutuhkan ilmu yang mumpuni agar bisa menghasilkan uang. Karena Dalam kehidupan sehari-hari, sayur, buah dan sus pasti ada di meja makan untuk konsumsi masyarakat. Kebutuhan sayur, buah dan susu ini termasuk kebutuhan pokok karena termasuk makanan yang wajib ada, demi menjaga kesehatan. Sayur-mayur dan buah-buahan dan susu ini termasuk dalam salah satu jenis bisnis agribisnis.

Agribisnis adalah bisnis berbasis usaha pertanianatau bidang lain yang mendukungnya, baik di sektor hulu maupun di hilir. Penyebutan "hulu" dan "hilir" mengacu pada ppetani dan peternakngan pokok bahwa agribisnis bekerja pada rantai sektor pangan (food supplychain). Agribisnis, dengan perkataan lain, adalah cara ppetani dan peternakng ekonomibagi usaha penyediaan pangan. Sebagai subjek akademik, agribisnis mempelajari strategi memperoleh keuntungan dengan mengelola aspek budidaya, penyediaan bahan baku, pascapanen, proses pengolahan, hingga tahap pemasaran. Istilah "agribisnis" diserap dari bahasa Inggris: agribusiness, yang berasal dari agriculture (pertanian) dan business (bisnis). Objek agribisnis dapat berupa tumbuhan, hewan, ataupun organismelainnya. Kegiatan budidaya merupakan inti (core) agribisnis, meskipun suatu perusahaan agribisnis tidak harus melakukan sendiri kegiatan ini. Apabila produk budidaya (hasil panen) dimanfaatkan oleh pengelola sendiri, kegiatan ini disebut pertanian subsisten, dan merupakan kegiatan agribisnis paling primitif. Pemanfaatan sendiri dapat berarti juga menjual atau menukar untuk memenuhi keperluan sehari-hari

Padahal agribisnis adalah peluang bagi Petani dan peternak untuk mengambil kesempatan agar menghasilkan keuntungan yang berlimpah. Kebutuhan akan pangan sangatlah tidak terbatas, sehingga agribisnis adalah bisnis yang punya peluang cukup besar di masa kini maupun di masa yang akan datang.Dan bila kualitias produk Agribisnis ini memiliki karakteristik produk yang sesuai dengan keinginan konsumen, Petani dan peternak bisa memiliki daya saing yang tinggi di pasar domestik dan juga mancanegara.

Pembangunan perdesaan sangat diperlukan untuk Indonesia karena sebagian besar penduduk Indonesia melakukan pertanian sebagai mata pencaharian, dan mereka tinggal di perdesaan Dalam usaha mempercepat laju pertumbuhan sektor agribisnis perdesaan, petani dihadapkan dengan kondisi yang serba lemah (modal, skill, pengetahuan dan penguasaan lahan) dapat ditempuh melalui penerapan sistem pengembangan (system of development) agribisnis. Di Indones ia sejak dilaksanakan pembangunan pertanian, telah diterapkan beberapa sistem pengembangan pertanian berskala usaha baik untuk komoditi pangan maupun non pangan.

Strategi Pemberdayaan Agribisnis Perdesaan muncul dari permasalahan adanya ketimpangan pembangunan wilayah antar kota sebagai pusat kegiatan dan pertumbuhan ekonomi dengan wilayah produsen sebagai pusat kegiatan pertanian yang kurang berkembang. Pembangunan sektor pertanian sekarang adalah sangat penting, karena apabila pembangunan sektor ini di wilayah tersebut menjadi tidak berhasil dikembangkan, dapat memberi dampak - dampak negatif terhadap pembangunan nasional secara keseluruhannya, yaitu terjadinya kesenjangan yang semakin melebar antar wilayah dan antar kelompok antara lain mengenai tingkat pendapatan. Pengembangan agribisnis di perdesaan merupakan pilihan tepat dan strategis untuk dapat menggerakan roda perekonomian dan pemberdayaan ekonomi masyarakat perdesaan. Hal ini memungkinkan karena adanya kemampuan yang tinggi dari agribisnis dalam penyerapan tenaga kerja, mengingat sifat industri pertanian yang padat karya dan bersifat massal dengan berbasis pada masyarakat dalam upaya meningkatkan perekonomian di perdesaan.

Desa Cipatat Kec. Cilengkrang, Kelurahan Ciporeal, Jawa Barat, merupakan daerah yang mempunyai potensi baik untuk dijadikan lahan atau tanah untuk Agribisnis, 
namun potensi ini tidak dimanfaatkan secara maksimal oleh masyarakat sekitar desa tersebut, dimana lahan disana terlihat tidak terpelihara dan tertata untuk lahan pertanian, perikanan,dan peternakan. Sementara dekat daerah Desa Cipatat terdapat lokasi Wisata Alam "Dewi Layangsari" dimana tempat wisatanya bertajuk pempetani dan peternakngan kota bandung dengan tempat duduk lesehan bergaya joglo sunda.Hal merupakan peluang untuk membuat wisata alam "Back to Nature

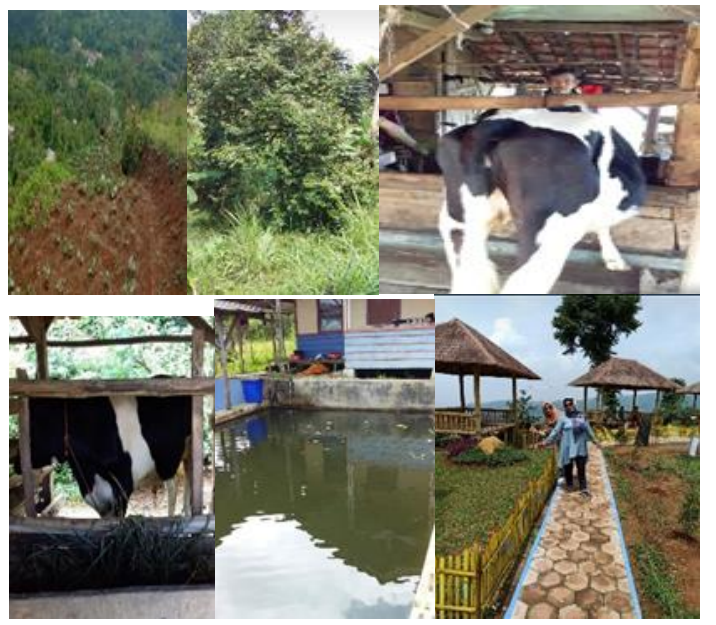

Gambar 1. Desa Cipatat Kec. Cilengkrang,

Kelurahan Ciporeal, Jawa Barat

Bagaimana menjalankan roda bisnis di pasar-pasar Lokal dan Mancanegara . yakni, apakah akan mengekspor, merundingkan suatu pemberian lisensi atau pertanian waralaba, mendirikan usaha patungan, atau mendirikan anak perusahaan yang dimiliki sepenuhnya. Meskipun secara prinsip pilihan pasar dan cara masuk merupakan keputusan yang terpisah, karakteristik khusus negara dan juga jalan masuk pasar internasional serta strategi ekspansi akan berdampak pula atas pilihan cara masuk.

Disejumlah negara berbagai karakteristik negara, seperti ukuran pasar, tingkat pertumbuhan, stabilitas politis, risiko lingkungan, kondisi operasi, dan infrastuktur, berdampak atas ketersediaan manajemen mengucurkan sumber daya untuk sebuah negara atau pasar tertentu dan juga cara masuknya. Pasar kecil kerapkali paling baik dilayani melalui pengeksporan atau pemberian lisensi, sebagai contoh. Demikian pula, manajemen mungkin menghendaki pembatasan komitmen sumber daya ke negara-negara dengan tingkat risiko yang tinggi atau infrastruktur yang buruk melalui perjanjian pemberian lisensi atau usaha patungan dengan mitra lokal. Sama halnya, jika manajemen berharap dapat memasuki sejurnlah negara secara cepat, sumber daya dan waktu yang dibutuhkan untuk mendirikan anak perusahaan yang dimiliki sepenuhnya mungkin akan menghambat, yang mengakibatkan perusahaan menggunakan cara pemberian lisensi atau usaha patungan.

Karakteristik produk, sifat permintaan, hambatan perdagangan, tujuan manajemen, dan sasaran ekspansi juga mempengaruhi keputusan pernililian cara masuk. Produkproduk berukuran besar dengan nilai jual rendah, sebagai umpama, membutuhkan lokasi produksi yang dekat dengan pasar disebabkan biaya pengirimannya-sekalipun biaya ini dapat diimbangi oleh skala ekonomis produksi. Salah satu perkembangan. paling signifikan dalam praktik dunia usaba dewasa ini adalah pertumbuhan pesat aktivitas internasional. Ekspor, investasi langsung asing dan penentuan sumber pengadaan produk dan komponen di luar negeri telah merebak secara dramatis. Dalam situasi seperti itu. banyak perusahaan yang memasuki pasar internasional untuk mencari sumber komponen secara lebih efektif dan memasuki pasar produk yang bertumbuh yang lebih menjanjikan dibandingkan pasar domestik

Konsep masuk pasar (market entry) berkaitan dengan kemudahan atau kesulitan di dalamnya perusahaan dapat menjadi anggota kelompok perusahaan yang bersaing dengan menghasilkan substitusi erat untuk produk yang mereka tawarkan. Perusahaan harus mengembangkan seperanglcat produk, aset, dan aktivitas manajemen untuk pasar baru yang disusupi Kepentingannya di sini terletak pada pasar internasional baru. Masuk yang berhasil akan tergantung pada sejumlah faktor. Hal ini tergantung pada bagaimana perusahaan:

- Menggunakan informasi peluang untuk rnenyusup ke pasar yang menguntungkan.

- Mengakses sumber daya yang produktif.

- Mengakses pasar.

- Mengatasi rintangan masuk pasar.

Dalam, banyak kejadian, perusahaan mapan unggul terhadap perusahaan baru dalam kemampuan mereka mengatasi 
hambatan-hambatan sumber daya dan pasar, dan mencapai skala ekonomis operasi. Masuk pasar telah menjadi ujian tertinggi bagi kemampuan kompetitif Agribisnis adalah peluang bagi Petani dan peternak untuk mengambil kesempatan agar menghasilkan keuntungan yang berlimpah. Kebutuhan akan pangan sangatlah tidak terbatas, sehingga agribisnis adalah bisnis yang punya peluang cukup besar di masa kini maupun di masa yang akan datang.

\section{METODE}

Adapun metode pelaksanaan yang akan dilaksanakan adalah Permasalahan Prioritas Mitra dengan Edukasi dan Pembinaan para petani dan peternak dalam Memasuki Pasar Lokal dan Mancanegara:

1. Survey Ke lokasi PKM

2. Pelatihan dan Pendadaran Materi di lokasi Bentuk Diskusi Group

3. Analisis Hambatan Para Petani dan Peternak dalam Menjalankan Agribisnis dan Bisnisnya.(Analisa SWOT)

4. Analisa Peluang Pasar dan Bisnis

5. Pembinaan dan Edukasi Dalam Menjalankan Agribisnis dan Manajemen Bisnisnya

\section{HASIL DAN PEMBAHASAN}

Dalam memulai sebuah bisnis di bidang agribisnis, harus melakukan berbagai trik dan tips yang kreatif. Memulai usaha ini juga mengharuskan untuk menetapkan peta menuju kesuksesan.Ddi Indonesia saat ini sektor agribisnis adalah sektor yang hanya menjual hasil produksi dalam bentuk mentahan. Jika diolah dan dikemas dengan apik, harganya bisa menjadi lebih tinggi.

Agribisnis adalah usaha yang memerlukan strategi matang dalam menghadapi segala tantangan yang tidak mudah. Apalagi saat ini pertanian kita sudah memasuki revolusi industri 4.0 yang menggunakan pertukaran data untuk proses produksi.

Agar Petani dan peternak bisa menjalankan agribisnis dengan maksimal, berikut ada beberapa tips dalam memulai bisnis Agribisnis:

- Agribisnis adalah bisnis yang terdiri dari banyak bidang yang bisa dijalankan. Mulai dari farmasi, sektor penyediaan energi, dan juga teknologi pangan. Sebelum memutuskannya, lebih baik Petani dan peternak kenali dulu mana yang lebih tepat bagi Petani dan peternak.

- Penggunaan media tanam seperti gelas bekas atau polybag sangat cocok bagi Petani dan peternak yang baru ingin memulai bisnis ini. Agribisnis adalah peluang usaha yang tidak perlu lahan luas. Petani dan peternak bisa melakukannya di media yang bisa digantung.

- Menganalisa target pasar bisa menentukan Petani dan peternak melakukan eksekusi yang tepat sasaran. Agribisnis adalah usaha yang membutuhkan analisis secara matang mulai dari cara penanamannya hingga target pasarnya.

- Agribisnis adalah usaha yang tidak selalu memerlukan lahan yang luas. Cobalah cara vertikultur dalam penanaman bibit. Bagi Petani dan peternak yang memiliki lahan yang sempit, Petani dan peternak bisa melakukan budidaya dengan metode yang satu ini.

- Lakukan pencatatan secara terperinci dan pembukuan yang baik agar alur keuangannya bisa terpantau secara transparan. Petani dan peternak bisa melakukan pembukuan secara manual dalam memulai usaha. Agribisnis adalah usaha yang memerlukan ketepatan dalam menghitung jumlah persediaan bibit agar tidak terjadi ketimpangan produksi.

Setiap bisnis tentu tidak tiba-tiba sukses begitu saja. Ada beberapa tips dan trik yang harus dilakukan untuk membuatnya berhasil. Para pelaku agribisnis merangkul para akademisi dalam mengembangkan usaha tersebut untuk meningkatkan keuntungan dan hasil produksi.Agribisnis adalah usaha yang tidak mudah dalam memulainya, terutama dalam kesiapan modal. Jika Petani dan peternak memiliki properti tanah, Petani dan peternak bisa memanfaatkannya sebagai modal awal. Bagi Petani dan peternak yang baru dan sedang menjalankan agribisnis, lalu ingin membuatnya menjadi sukses, berikut adalah beberapa tipsnya:

- Untuk menghasilkan bahan pangan yang berkualitas tanpa menimbulkan ancaman terkait kesehatan, Petani dan peternak bisa menanam bahan pangan dengan 
organik. Harganya memang lebih mahal karena tidak melibatkan bahan kimia apapun dan perawatannya cukup rumit.

- Maksimalkan gadget sebagai media promosi Petani dan peternak untuk menarik para calon konsumen. Agribisnis adalah ilmu yang cukup baru berkembang di Indonesia. Jadi, coba buatlah video tutorial ataupun artikel tentang bagaimana menjalankan bisnis agribisnis yang sukses.CRM dengan pelaku bisnis dijalin dengan melalui Instansi Pemerintahan terkait.

\section{PENUTUP}

\section{KESIMPULAN DAN SARAN}

1. Target agribisnis adalah peluang bagi para petani dan peternak untuk mengambil kesempatan agar menghasilkan keuntungan yang berlimpah. Kebutuhan akan pangan sangatlah tidak terbatas, sehingga agribisnis adalah bisnis yang punya peluang cukup besar di masa kini maupun di masa yang akan datang. Agribisnis adalah usaha yang membutuhkan pengalaman dan ketelatenan. Apapun jenis usaha agribisnis yang Petani dan peternak pilih, pastikan untuk selalu menjalaninya dengan sungguh-sungguh. berkunjung langsung ke petani yang sukses dan ikuti beberapa pelatihan agar bisa belajar langsung dari ahlinya.:

2. Dengan adanya strategi pengembangan agribisnis pedesaan, pemerintah sebaiknya dapat melaksanakan berbagai program dan kebijakan yang tepat dan sesuai dengan analisis lingkungan di Desa Cipatat, untuk mewujudkan pertanian modern yang berbasis di pedesaan. Pemilihan komoditi yang akan dikembangkan dan pasar yang akan dituju merupakan hal penting yang harus diprioritaskan sesuai dengan potensi yang ada di pedesaan. Strategi pengembangan agribisnis pedesaan juga sebaiknya dapat memberdayakan masyarakat miskin dan masyarakat ekonomi lemah agar dapat meningkatkan kesejahteraannya dan memajukan perekonomian desa.
3. Dari alternatif-alternatif strategi pengembangan agribisnis pedesaan dan strategi pemberdayaan ekonomi masyarakat di Desa Cipatat, sebaiknya dilakukan secara bertahap dan dalam pelaksanaannya dilakukan pembimbingan dan pengawasan agar tujuan dari pelaksanaan strategi tersebut dapat tercapai dan tepat sasaran

\section{DAFTAR PUSTAKA}

Abd.Rauf, M. M. M. N. A. dan R. (2016). Strategi Pengembangan Agribisnis Di Kecamatan Ampana Tete Kabupaten Tojo Una-Una Strategy of Corn Agribusiness Development in Ampana Tete Sub District of Tojo Una-Una Regency. J.Agroland, 23(April), 40-49.

Amzeri, A. (2018). Tinjauan perkembangan pertanian dan peternakan di madura dan alternatif pengolahan menjadi biomaterial. Jurnal Ilmiah Rekayasa, 11(1), 74-86. http://journal.trunojoyo.ac.id/rekayas a

Gede, I. D., Sarjana, R., Darmawan, D. P., Wayan, N., \& Astiti, S. (2017). Merunut Potensi Agrobisnis Sebagai Pengusung Utama Komoditas Ekpor Provinsi Bali. 5(1), 103-110.

Haque, M. G., Nurjaya, N., Affandi, A., Erlangga, H., \& Sunarsi, D. (2021). Micro Financial Sharia Non-bank Strategic Analysis: a Study at BMT Beringharjo, Yogyakarta. Budapest International Research and Critics Institute (BIRCI-Journal): Humanities and Social Sciences, 4(2), 1677-1686.

Utilization Strategy to Improve Food Security in Kuwu Village ,. Journal of Economics and Business, 1(17), 30-40. http://indicators.iseisemarang.or.id/in dex.php/jebis\%0AVillage

Panikkai, S., Hidayat, W., \& Bulukumba, U. M. (2019). Spatial Planning and Strategy for Improving The Production of Hybrid Corn Seeds In Bone District. Jurnal Manajemen Agribisnis, 7(2), 147-154.

Rangkuti, F. (2016). Analisis SWOT: Teknik Membedah Kasus Bisnis. PT. Gramedia Pustaka Utama. Jakarta. 